\title{
ワークショップ 1：妊産婦のカを引き出すケア
}

\section{妊産婦の力を引き出すケア}

\author{
座長:助産院ていだ 仲西三枝子 \\ 医療法人社団スズキ病院 八木橋香津代
}

私は長年施設で助産師として働き、現在は開業しております。開業にあたり助産院で 3 週 間の研修をさせて頂きましたが、そこで 3 日間かかって無事出産された初産婦との出会いは 貴重な体験となりました。正常と異常を見極める能力を発揮し、待てるという判断、その間 産婦に寄り添、、不安の軽減に努め、本人に楽な姿勢や体位を選んでもらい、マッサージや足 浴、温かい飲み物、少しでも休めるように環境を整えるなどのケアが行われていました。そ うした助産師のケアに対して、産婦もまた安心しきって、自分の力を信じて前向きに頑張る 姿は、今までの病院では経験したことのない光景でした。

私のこれまでの経験から、病院では女性は自分の力を活かしたお産ができにくい環境にあ ると思います。女性は主体性を持てなかったり、「わがまま」と言われるので自己主張できな かったりしがちでした。一方、ケアにあたる助産師も病院というシステムの中で、医師の指 示のもとに動かざるを得なかったりで、お産に対する思いがあっても産婦の声に十分応える ことができないと感じていました。しかし、病院でも妊産婦の要望に耳を傾け、妊産婦に「産 む気」にさせたいと、産科医をはじめスタッフが一丸となって取り組んでいる施設もありま す。相南鎌倉総合病院の取り組みを読み感動しました。

吉村典子氏は「子どもを産む」の著書の中で「いいお産をするにはやはり、助産師に任せ てしまわないで、お産をするのは自分という自覚を持つことが大切である。お産は産婦が産 むものであり、助産者はいくら優秀な技術者であろうとお産を手助けしてあげることしかで きない。産婦にとっても、助産者にとっても一番いい動機つけは、産婦を産む気にさせるこ とである。日頃、常に妊産婦と共にある助産師こそ、産婦を“産む気にさせる”工夫を日頃 の助産体験の中からさぐりだしてもらいたい」と述べています。また、そのためには産前教 育の整備充実が重要であるが「残念ながら、その大切さに気づき独自に力を傾けている施設 は大変少ない」と指摘しています。そして現場の多忙さ以外に産前教育が整備されない要因 は、産科医や助産師などが “お産の専門家”である自分たちが分かっていれば、「医療をうけ る側の産婦が必死で知る必要もないし、知らせるために大きな努力も払う必要もない」とい う考えが助産者の胸の内にあるためではないかという指摘に、助産師各自が胸に手を当てて 考えてみなければなりません。

そこでこのワークショップでは「妊産婦の力を引き出すケア」について、相南鎌倉総合病 院の長谷川充子先生、聖路加国際病院の井村真澄先生、開業加瀬井房子先生の 3 人の皆様 方に話題提供をいただき、会場の皆様と有益な意見交換ができればと考えています。 


\title{
産婦の主体的な出産をサポートする
}

\author{
湘南鎌倉総合病院 長谷川充子
}

\section{はじめに}

人類が誕生してから脈々と続いているお産が、今ここにきて注目されている。 短時間に陣痛から解放され、分婏を安全に終了したいと願わない人はいない。しかし、どん な分婏経過をとるかは、陣痛が始まってみないとわからない。私達助産師は、産婦が安心し て、無事に分婏を終了することができるよう、どのように支援したらよいかを考え、日々実 践している。ここでは、そうした援助を紹介し、今後の支援における展望を述べてみたい。

\section{実践の内容}

不必要な医療介入をせず、母親の婏出力と赤ちゃんの生まれようとする力を信じて、助産 師はサポートをしている。分婏の進行状況は、予測が困難なことも多い。特に、陣痛開始か ら 20 時間以上を経過する頃になると、早く辛い陣痛から解放されたくなった産婦からネガ ティブな言動が見られることも多くなる。また、心配のあまり、何とか早く生ませられない かと、家族が詰め寄ってくることもある。陣痛が微弱なのか、胎児の大きさあるいは回旋異 常汃、陣痛の恐怖からくる緊張によるものか、産婦の一番身近にいてサポートしている助産 師に回答を求められる。

何ら、医療的な介入をしなくてよいと判断できたなら、産婦と見守る家族に納得できる説 明をし、主体的に分婏に向かえるようサポートすることが大切な援助となる。そうした産婦 が一番望むことは、「一人にしないでほしい」ということと、いつもそばにいて、温かな声か けとタッチングケアである。このケアが分婏のスムースな経過をもたらしていることが多い と感じる。

当院における産婦の年齢と分婏所要時間（第 I 期）を見ると、図 1 のように 35 歳以上の 初産婦では、30 歳以下の初産婦より 10 時間を上回る分婏所要時間がかかっている。経産婦 では、年齢による有意差はみられていない。「高龄だから分婏に時間がかかる」と頭から考え ている産婦に対しては、精神的緊張を解くことができるようサポートをする。腰をさすり、 指圧を好む産婦には、取り入り? 足浴によって骨盤内の血液循環を促し、分娩第 II 期が遷延 していても、シャワー浴を行い、積極的に体を動かすケアとして、ストレッチ、腰のローリ ング、歩行を促す。

陣痛室から分婏室に入室すると、陣痛が遠のく産婦を経験したことから、よりアットホー ムな雲囲気を分娩室に取り入れることにした。分婏室の器械棚を取り去ることで産婦の恐怖 
心を取り除き、自宅で分婏するのと同じようにリラックスできるよう和室に改装することで、 心の緊張を緩和して産道の弛緩、ひいては産婦の主体的な出産を目指している。

出産は自然のプロセスに逆らうことなく、排便と同じで生理的な反射運動であり、誰でも できる運動である。肩に力を入れず、できるだけ自然体で臨む。私らしいお産がしたいと、 医師や助産師に伝えられるようにすること。医療者側の都合で、仰卧位一辺倒だった病院の 分婏台での分婏姿勢は今後見直されつつある。

年令と分娩時間(2000/9/1-2002/10/31)*

\begin{tabular}{|l|l|l|l|l|l|}
\hline & 年令 & $<30$ & $30-34$ & $35-39$ & $40-$ \\
\hline \multirow{4}{*}{$\begin{array}{l}\text { 初 } \\
\text { 産 }\end{array}$} & no & 429 & 374 & 123 & 18 \\
\cline { 2 - 6 } & SVD & 353 & 259 & 65 & 10 \\
\cline { 2 - 6 } & 分婏第1期(時) & 18.9 & 17.2 & 29.5 & 26.6 \\
\cline { 2 - 6 } & 分婏第2期(分) & 144.3 & 210.9 & 227.9 & 224.6 \\
\hline \multirow{4}{*}{$\begin{array}{l}\text { 経 } \\
\text { 産 }\end{array}$} & no & 172 & 341 & 168 & 20 \\
\cline { 2 - 6 } & SVD & 158 & 297 & 136 & 18 \\
\cline { 2 - 6 } & 分婏第1期(時) & 6.6 & 7.8 & 7.5 & 6.5 \\
\cline { 2 - 6 } & 分婏第2期(分) & 40.1 & 50.6 & 44.1 & 37.2 \\
\hline
\end{tabular}

*好娠35週以上 総数: 1645 件 自然分婏数: $1296(78.8 \%)$

初産㛿亡経産㛿の分娩第1期(2000/9/1-2002/10/31) 湘南鏻會総合病院産㛿人科*

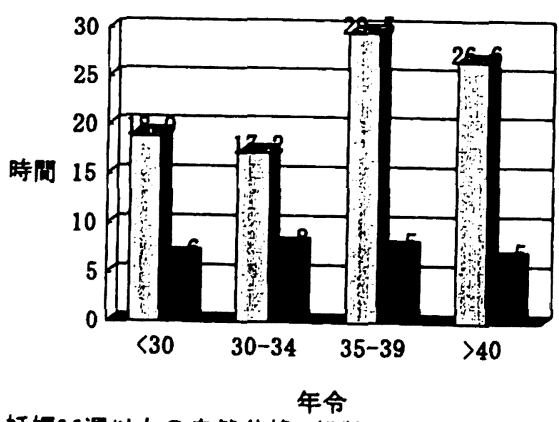

*娃娠35遗以上の自然分晩 総数: 1296件
初産媂と経産婷の分娩第2期(2000/9/1-2002/10/31) 湘南镂合総合病院産䀯人科*

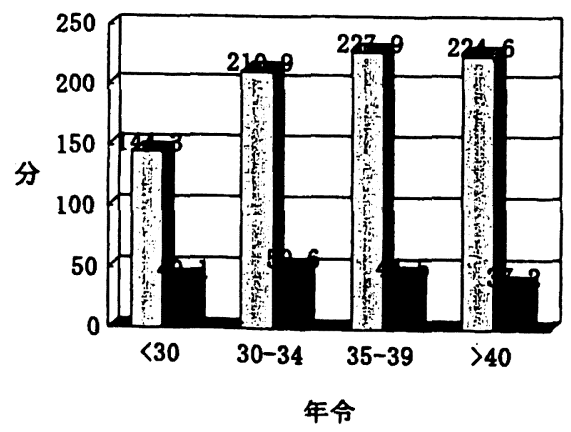

*妊娠35週以上の自然分婏 総数: 1296 件 


\section{お互いに支えあえる仲間作り・家族作りの 「魰衣」をめざして}

聖路加国際病院産科新生児科 井村 真澄

\section{〈聖路加国際病院における妊娠期母親学級・両親学級の実際＞}

当院では、妊娠初期から産後までの期間、同一助産師による受け持ち担当制、同一参 加メンバーで構成された小グループ制の母親学級を開催しています。妊娠期に 5 回、産 後に 2 回のクラスを開催しています。この他、両親学級をはじめ助産師なんでも相談、 里帰りクラス、おじいさま・おばあさまのためのクラスを開いています。

私たちがめざしているのは、(1)参加者同士がお互いに仲間と出会い理解を深め、相互 に支え合えるグループに成長すること、(2)各個人が妊娠中自分の体の声に耳を傾け、自 分なりの対処法を見つけること、(3)妊娠と出産を、自分自身と夫婦のこととして受け止 めて対応し、決定するための知識と技術を持つこと、(4)参加者が個別的問題について、 受け持ち助産師と十分に話し合えること、などです。

これらのプログラムを通して、少人数の特性を活かしたグループ活動を行っていきま す。最初のオリエンテーションでは、参加者の一人一人が積極的に参加して「自分たち の」グループを作っていきましょうと奨励します。しかしそうは言っても、はじめのう ちは助産師にばかり視線が集まります。それをその都度「どうぞ皆さんに向けてお話し て・・」と、メンバーに向けた視線に置き換えていただきます。この視線の向きが変 わることによって、グループダイナミックスに変化が起こり、グループとして動き始め ます。個人の意識や態度も変わっていきます。「私一聞く人、助産師一教える人」と、妊 娠や出産について何でも助産師に聞けばいいと決め込んでいた妊婦さんたちは、回を重 ねる毎に「私一自分で考え準備し実際に生む人、助産師一そばにいてよく聴き時々助け 舟を出す人」と、主客が置き換わってきます。ここまで来ればしめたものです。

さらに両親学級では、ご夫婦で支えあいながら出産に臨めるように、パートナーにも 出産の経過を理解し、具体的にどのように付き添ったらいいのか実地練習していただく 機会も提供します。「これは、夫婦愛の具体的表現そのものだね。」とおっしやった、あ るパートナーの言葉が印象に残っています。

さて、受け持ち助産師が必ず出産に付き添えるわけではありませんが、入院後・出産 
後には必ず訪室し、一緒に妊娠・出産の振り返りをします。これは、お母さんと助産師 にとって、お互いの体験とかかわりをフィードバックする大切な場面です。さらに、入 院中、かつての同志だったメンバーに会って話し、励ましあうという母親同士のかかわ りは、お互いに格別な力を与え合うようです。

\section{＜産後クラス ラッコの会の実際とタッチケア＞}

一ヶ月のラッコの会では、自宅または実家での隠遁生活から抜け出してきたお母さん と赤ちゃんが一堂に会します。その日に至るまでの辛さや楽しさ奮闘ぶりをみんなで話 しあうなかで、ちょっぴり心配だったことや不安だったことが、「な〜んだ、みんなそう なんだ。」「これでいいのね。」と解決されていく場面です。「妊婦時代からの旧友」の母 親姿とその赤ちゃんを実際に見て、仲間からのサポートを受け、そして自分で納得する。 このように前に進んで行くことが、お母さんたちの自信につながるのでしょう。小さな 自信を得た新米お母さんたちは、その次の段階として、わが子に合った育児を自分で工 夫し始めていきます。お母さんたちがもてあまし気味の疑問には、後方支援隊である助 産師と小览科医がお答えします。

三ヶ月のラッコの会では、母親としてさらにパワーアップしたお母さんと赤ちゃんが 集まってきます。まずは、仲間との再会を喜び合うことから始まります。ひとしきり話 が弾んだ後に、タッチケアをご紹介します。

ここではタッチケアを、単なる手技として提示するのではなく、赤ちやんに触れる・ なでる・さするというコミュニケーション手段を通した親子の深いかかわり合いのチャ ンスとしてご紹介します。タッチケアを通してもっとわが子を感じ取り、理解し、世界 一素敵なわが子を味わい尽くしていただきたいと思っています。見つめ合い、じっくり と語りかけ、肌と肌を触れ合わせ、お母さんが赤ちゃんにメッセージを送る。赤ちやん もお母さんにきらめくようなメッセージを返す。赤ちやんからそれでいいんだよママ、 と保証をもらい育児への自信を深めていく。そしてお互いが心地よさとともにさらに深 く理解しあっていく。そのようなお互いを育てあう親子の関係性を目指しています。こ の場に及んで助産師の役回りは「黒衣」そのものですし、さらには「後見不要」もまた 良しです。

タッチケアは、どちらかといえば辛さも多く切羽詰った気持ちの育児初期において、 ほっとできるひとコマと、深い味わいのある親子の上質なひと時を与えてくれるでしょ う。わが子に一番いいことをしてあげられるのは、母親であるこの私とパートナーであ る私の夫だ、と自然に思うことができる小さなきっかけ作りになることを願っています。

妊娠・出産・育児期のご両親へのより望ましいかかわりを目指しながらも、道半ばの 現在ですが、私たちの体験を助産師の仲間と共有できる機会を頂いたことを、心より感 謝致します。 


\section{ワークショップ1：妊産婦のカを引き出すケア}

\section{妊産婦さんにやる気を起こしてもらえる対応を！}

助産院 ベビーヘルシー美蕾 瀬井 房子

私は助産院開業して 17 年目になりますが、「妊産婦の力を引き出すケア」という玄 一マをいただき、改めて当助産院のケアについて省みるチャンスとなりました。私が経 営する助産院はお世辞にも、「便利」さや「都会性」のないところで、ロケーションと しては山の中で周囲は田園地帯、一番近くの産婦人科に行くには 10 キロ近くかかると 言うところです。しかし幸いなことに年間百数十人の方が利用して下さいます。

この様な地理的環境不便なところで、どのようなケアをしているかと申しますと、「女 性として、行ってほしくないことには極力手を出さない」「ケアの相手を自分に置き換 えて”もし自分がケアを受ける立場だったら”という視点でケアを行う」など

それぞれの時と場合によって異なったケアーの仕方があると言うことを第一におい てよりレベルの高い物を求めて来たというのが現状ですが、では妊産婦の力を引き出す ケアとはどんなことかと考えたとき、妊産婦さんに「やる気を起こしてもらえる対応の 仕方」と言うことになります。

私達は

1）妊娠初期から出来るだけ相手の方を理解する努力を行っています。それは家族関係 や友人関係、住居関係とあらゆる点での話題性を探ることからはじめます。

2 ) 妊娠中の生活指導、先にも書きましたように何かあったとき、援助をお願いする病 院までの距離が遠いことから、妊娠中に是非健康な妊娠生活を送っていただくよう な生活指導を外来での妊婦検診や、出産教室を通じて行っています。

3 ）家族の協力、当院は町中からやや離れていることや、公共の交通手段が悪いことな どから、ほとんど自家用車を使い家族での検診が多く、夫や子供達が診察室にも入 ってきます。このような時を有効に活用し妊娠中に体を動かすことの重要性と家族 の協力を取り付けるようにしています。

4 ）お産は自分の力で、自分が主役で産む事へのアプローチを事あるごとに話します。 そして助産師はあくまで「黒子」に徹する様にしています。我々助産師が主役に なれば、妊産婦さんは人を頼ってしまいます。自然の力を充分に活用し、もてる 自己を出すための援助を行うように努力しています。 
出産後は比較的早くから入浴をしていただきます。それは出産で疲れた筋肉をほ ぐし疲労回復を計るのみではなく外陰部の清潔をも兼ねています。我々助産師は薬品 を使うことが出来ません、それなら「消毒の第一歩は流水と石鈿」という基礎看護で 学んだ消毒の基本にそって、このようなケアーを行っています。また産後の全身マッ サージはアロマオイルを使用して心と体の癒しに勤め自然の回復力を高める努力をし ています。

以上色々書きましたが妊産婦の力を $100 \%$ 引き出したお産をしていただくため の教育が一番大切ではないかと思い日々努力しています。その方法や言動については シンポジュームにおいて発表する予定です。 


\title{
助産の質向上のための研究
}

\author{
座長:沖縄県立看護大学 玉城 清子 \\ 金沢大学医学部保健学科 島田 啓子
}

医学の急速な発展により、通常の正常な妊娠分婏に加え、合併症をもつ妊産婦、不妊症 治療後の妊産婦等医学的にハイリスクの人たちも助産師のケアの対象となってきています。 助産師のケアには、専門職として独自の判断で行える行為と医師の指示で行う行為の 2 つ がありますが、両者に共通するのは対象者のニーズに合致するとともに最善の医学・科学 的知識にもとづいたケアの提供だといえます。ここでは助産の質を、妊産婦ケアのための 助産婦の知識・技術の質と定義しておきます。我々助産師は妊産婦にこれが最善のケアと 自分が信じていることを実践しています。信じていることは個々に異なる場合があるため、 助産師の勤務施設によってケアが異なる場合があります。例えば、正常に経過している産 婦に対しては、ある施設では医療介入を極力押さえ、対象のニーズにそったケアをしてい るのに対し、ある施設では陣痛開始後はハイリスクとの考えから絶飲食にしたり分婏監視 装置を持続的に装着しているというのもあります。なぜ、同じ現象に対し異なったケアが 行われるのでしょうか。米国医療の質委員会・医学研究所は、「最善の診療とは、十分な教 育研修と経験を積んだ臨床担当者が、現時点での最新最善のエビデンスを患者の価值観を 重視しながら注意深く、分別をもって活用することから生まれる。」と述べています。つま り最新最善のエビデンスがガイドラインとなりますので個々の施設でケアが異なるのは少 ないと考えられます。

助産の質を向上させる、つまり最善のケアを提供するためにエビデンスを求める必要が あります。米国医療の質委員会・医学研究所は、エビデンスの 4 つのタイプの研究として1) 実験室での研究、2）臨床試験、3）疫学的調查、4）系統的に集積された適切な検討を経た 個々の患者もしくは患者集団の症例報告の分析を含めた医療成果の調查をあげています。 我々助産師は日常業務の経験の積み重ねにより自分の信じる最善のケアをつくりあげ、提 供しています。しかし、それが客観性のある最善のケアになっているか今一度検討する必 要はないでしょうか。前述の 4 つのタイプの研究デザインの 2）から4）の方法を活用すれ ば自他共に認める最善のケアのための研究ができると思われます。 


\section{レビューにおける治療的自己利用の視点から}

聖母女子短期大学＼cjkstart和田サヨ子

\section{レビューに関する看護ケアの評価の視点}

一人一人の産婦にとって分婏期の体験は、どんな体験なのかという私の関心から質的 に取り組む事になった。

レビューは産婦と共に陣痛体験を振り返り、痛み体験を意識化し将来の陣痛に対処で きなくなる様な要素が入り込まないように「経験の統合」への援助により次回の陣痛体 験のパニック状況を防止することを目的としている。今回レビューを実施し、レビュー を終了後の産婦の反応は、2 5 名中 24 名（96\%）が肯定的に陣痛を受け止め意味づ けしている。分婏第 I 期〜 II 期の陣痛体験がほぼ否定的に受け止めていた産婦もレビュ 一によって明確に意味ある体験として意識化され受け止められるように変化している。

レビューを用いて調査した結果から、レビューがより効果的になるためのナラティブ アプローチとの関連を以下に述べる。

\section{質的研究とナラティブアプローチ}

Care とは、「行為」というよりも「関係」であると考える事が出来る。援助者とクラ イエントがどのような関係をつくるか助産師同士がどのような関係をつくるか、それが 「ケア」の内実を決定する。「ケア」が成り立つかどうかは、そこで何がやりとりされた かではなく、それがどのようなやりとりを可能にする関係であるかによって決まる。「ケ ア」とはひとつの「関係」である。

質的研究（系統的に集積された適切な検討）は、認識論的転換に至る探究である。ナ ラティブアプローチは物語が展開する場で、臨床を「語り」「物語」という視点から眺め 直すことである。ナラティブアプローチが主張するのは、援助者とクライエントが共同 で同じ問題に取り組むという「関係」である。一方が他方を指導しないという「関係」 である。一方が他方に何かを与えようとしたり、引き出そうとしたりしない「関係」で ある。このような「関係」によってケア的な関係・セラピューティックな関係が成立す ると考える。

ケアの「外在化」の視点

お互いが自分が適切だと思うケアのあり方を基準にして、相手のケアの不適さを非難 
しあっている日常性がある。ケアを個人に属するものではなく、個人と個人が織りなす 「関係」としてとらえれば、個人ひとりに責任を帰すことはできなくなる。

一方だけがいくら頑張っても変えられないのが「関係」である。「関係」は個人に「外 在」している。問題を個人に内在化させて考えている限り、変化すべきはその個人であ って、専門家はその指導者または援助者になるよりほかない。そして、このような役割 分担自体が「問題」を固定化し、より頑固なものにしていく。「問題」が個人の外部にあ ると考えれば、援助者とクライエントはその「問題」に対して、共に戦う同志となるこ とが出来る。大切なのはケアを「内在化」しないという姿勢であり、今、自分が相手と どのような「関係」を作っているのかにつ称に注意を払い続けることである。（図 1)

「外在化」は、ケアを能力だけではなく、「関係」としてつくり直す」ひとつの示唆を 与えている。セラピーとケアを対立的にとらえないと、ケアを関係としてとらえること ケアを内在化しない援助者の在り方が大切である。私達の行為や対処の選択肢を狭く限 定してしまわないことである。

\section{ナラティブとしてのケアの視点}

ケアを「関係」ととらえるならば、ケアをする人も、ケアされる人もそれぞれの物語 を生きているということになる。クライエントだけが理解されるべき特別の物語を生き るわけではない。援助者もまた独自の物語を生きている。クライエントに大切な物語が あるのと同様に、援助者にも大切な物語がある。両者は論理的に等価な存在であり、一 方が他方に優越すべき理由はない。関係」は二つの物語、すなわちクライエントと援助 者の二つの物語の出会いである。この二つの物語の出会いが二人の関係をかたちづくり、 ケアの具体的かたちを作っている。2つの物語は必ず相互に影響しあう関倸にある。

ケアによってクライエントの物語が変わるのだとすれば、援助者の物語も変わる。従 って私達はクライエントの物語に配慮すると同様の重さで援助者の物語に配慮しなくて はならない。援助者はこれまでどのようなケアの物語を生きてきたのか、そして今、ど のようなケアの物語を生きようとしているのかが問われる。本質的に看護ケアの評価は、 この視点でとらえることではないだろうか。

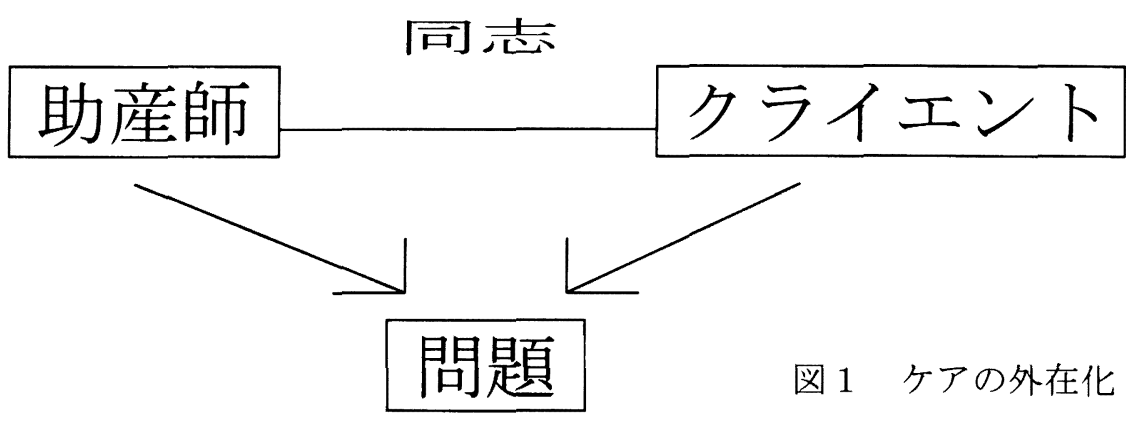


ワークショップ 2 : 助産の質向上のための研究

\section{研究における個人の福利と科学的・社会的利益}

広島大学医学部保健学科 横尾 京子

\section{助産の賢向上のための研究とは}

助産師として臨地で実践しているとき、 また、助産について教育現場で教えてい るとき、より良質の実践が可能となる よう意識する。

よりよい質を求めるのは、 助産を必要とする人々と 助産師双方が満足できる体 験を共有するためであり、 言葉を換えれば、実践を 通して社会的責任を果た すためである。

それは、右図に示した ように、助産の実践に用 いる知識や技術は研究に よって裏づけられ、かつ 臨地で広く実用され、個人 にとっての安全や安楽、

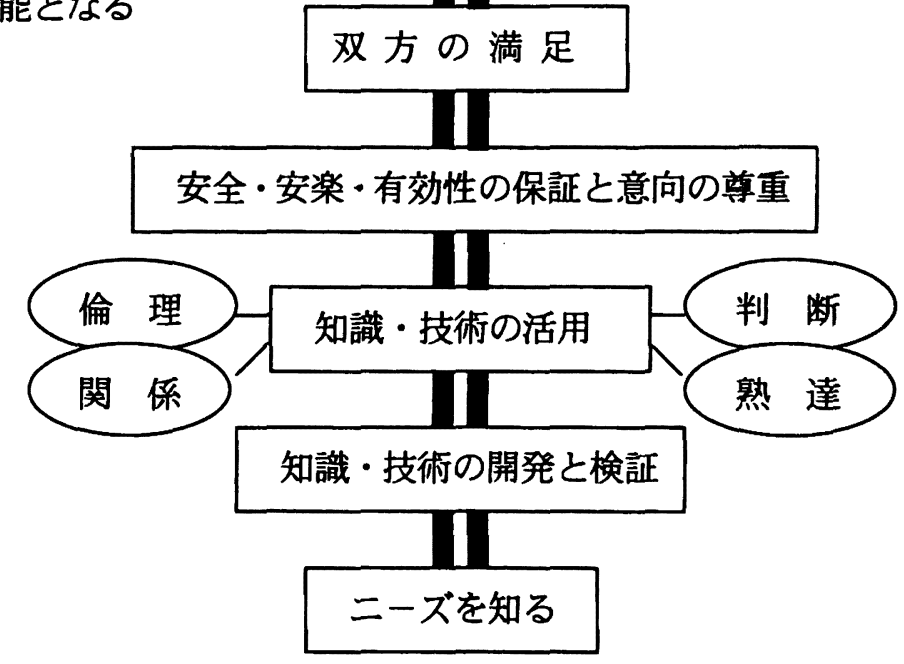

有効性、意向に沿うものであることが明らかにされることによって、その個人に意味のある ものになり、研究者はもちろん、実践家や助産を必要とする人々にとって満足のいくものに なろう。

しかし、研究成果が必ずしも助産の質向上に繁がるとは言えない場合がある。その理由と して、研究法が自体がもつ限界 (実験デザインが組めない場合)・研究者の研究や実践能力 (研 究意義への発想・研究方法の作成・データ収集・データ分析) ・対象者への倫理的配虑などが 考えられる。ここでは、倫理的な側面である個人の福利と科学的・社会的利益について考え たい。 


\section{研究における固人の福利と科学的·社会的利益}

助産の質向上に粲がる研究は、単に研究者の関心に留まらず、社会や個人のニーズに密着 したものであり、継続、発展させ、科学的に広く検証していく必要がある。それによって研 究自体が洗練され、対象や現象、因果に対する説明力をより獲得していくことができる。し かし、その研究過程では、研究の科学性と対象者の権利が対立することがあり、非意図的で あったとしても対象者に不利益を与える可能性がある。その可能性に対しては、「被検者の福 利に対する配虑が科学的および社会的利益よりも優先されなければならない（ヘルシンキ宣 言)」と研究者に警告が発せられている。

研究が助産の質向上を意図するものであったとしても、個人の意思を犠牲にすることはで きない。「完全な情報公開」・「自己決定の尊重」・「プライバシー保護」を保証することを前提 に、対象者が受ける不利益やリスク」と「研究成果（社会が受ける利益や看護上の貢献）」 とのバランスを、科学原則・法的原則・倫理原則の観点から検討し、最終的に、正当に認め られたものでしか対象者にアプローチすることはできない。

例えば、記録物から情報を得て助産活動をまとめ、公表しようとする場合、記録の対象で ある個人から承諾を得る必要がある。特に、助産活動をまとめるために個人情報の何を、ど のように使用するのか、また、どこで、どのように、なぜ公表するのかについて具体的に説 明する必要がある。仮りに全員の協力が得られなかった場合、その結果をどのように解釈す るかが問われることになる。

あるいは、介入法の評価研究において、その介入が経験的に優れているとわかっている場 合、同一施設内で、介入群と非介入群間比較によって検証しようとするデザインを組むこと は、倫理的には不可能となる。この場合は、方法や研究目的の修正が余儀なくされる。

倫理的配虑は研究に限界を生じさせることになるが、より説明力を持つ結果を得るには、 限界を超えるだけの研究を計画しなければならないということである。

\section{研究協力に伴う不利益やリスク}

身体的侵䇛や負担 : 状態の悪化・副作用・不快感・疲労感・退屈さ 心理的負担や情緒的ストレス：自己開示・内省・恐怖・怒り・不愉快さ

プライバシーの侵害 時間の浪費

経済的負担

文献 3）を参考に作成

\section{文献}

1) 日本看薜科学学会看護倫理検討委員会 : 看臀研究に関する倫理的配虑に関する検討, 日本看讙学会誌, 15(4) : 31-38, 1995.

2) 日本看護科学学会看護倫理検討委員会: 看謨系大学における研究の倫理審査体制の試案, 日本看護学 会誌, 18(1) : 60-70, 1998.

3) Polit,D.F. \& Hungler,B.P. : Nursing Research,Philadelphia,J.B.Lippincott, 1995. 


\section{助産研究と助産実践の橋渡しをめざして}

聖路加看護大学 江藤 宏美

\section{実践に役立つ研究}

研究は何のためにおこなうのかと問われると、目の前にある現実の問題を解決したり、䠛 床のあり方を変えるためにおこなったり、あるいは実践を見直し、疑問をもち、なぜそのよ うな行動をとっているのかなど、不確かな点を明らかにしていくために行われると答えるだ ろう。そして、目指すところは対象者の利益であると考える。近年、EBM/N の広がりとと もに、研究によって得られたエピデンスに基づいたケアが強く求められている。

\section{研究目的・研究方法の設定}

研究目的は、どのような現実の問題に根ざした疑問が出発点にあるかによって決まってく る。疑問を絞り込んで、明確に示す必要がある。そうでなければ、答えを探すのが困難にな る。基本的に、一つの研究に一つの目的が望ましい。

目的が決まったら、その臨床上の疑問ごとに存在する適切な研究デザインを選択する。介 入する群と介入しない群を比較し、介入の効果をみる介入研究。これは、おもに行った行為 を評価する時に用いられる。結果のバイアスを防ぐために無作為化（randomized）して、実 駼群と対照群を振り分ける作業を行う。そして、コホート研究、ケース・コントロール研究 などの繸断的な観察研究がある。コホート研究で分類される群は観察的に割りつけられ、そ れぞれの群を比較した結果が用いられる。その他、ケースシリーズ、症例報告など記述的研 究がある。

\section{結果を生かす}

目的にそって得られた研究結果は一つ一つ積み上げられて、少しずつエビデンスが広がつ ていく。研究は続けることが大切である。看護研究の意義は、研究成果が実践のなかで活用 されてケアの質の向上につながり、さらにそこから新たな研究課題が見出されることにある。

\section{これまでの研究}

現在取り組んでいるテーマは、新生児/乳児の睡眠·覚醒状態を明らかにすることである。 
この研究を始めた動機は、出産後の母親の混沌とした生活とことばで意思を伝えることの できない子どもとの関係の始まりに興味をもったことから始まった。出産に引き続き、子ど もがいる新しい生活が始まる。子どもはいつもおとなしく眠っているわけではなく、泣いて 母を呼んだり、その睡眠や覚醒は昼夜関保なく不規則に繰り返されることになる。育児書に あるように、3時間ごとに眠りから覚めて、授乳したらまた眠る、というような決まったも のではない。なかなか泣き止まない、あるいは眠ってくれないことは盖育者の不安感を漏り、 有児はつらいものになりかねない。

そこで、「子どもの眠りを予測することができれば、母親の気持ちに多少の余裕ができるか もしれない」と考元、研究に着手した。眠りを予測する指標として、未梢の皮虐温を用いる ことにした。それは、子どもが寝つかない時に湯たんぽなどで温めることで入眠する場合が みられたという経験による。研究は、「正常新生児の入眠時に、足底皮墟温は上昇するか」を 明らかにすることを目的とした記述研究であった。研究方法として、子どもの行動観察を通 して、睡眠から覚醒に至る意識状態の変化を把握すること、同時に、足底に皮膚温プローブ を貼り、1 分毎にモニタリングすることとした。日常生活場面での自然な状況を肉眼的に観 察するために、各家庭に出かけ昼間の時間に $3 \sim 5$ 時間測定した。結果は、ぐっすり眠る群 では入眠時に子どもの皮唐温が上昇しており、寝ない群では皮虐温か下降していた。つまり、 子どもの足底皮庙温は、入眠の予測指標になりうるという結果が得られたことになる。

次に着手したのは、夜間における生後 1 か月児の睡眠・覚醒に関することだった。出産後 1か月間はあまり外に出ることもなく、子どもの夜泣きや睡眠について高い割合で母親の心 配のもととなっていた。よって、家庭環境のもとで添い复をする日本の文化のなかで、夜間 の子どもの睡眠・覚醒について行動観察を行い、その経過を記述し、子どもの睡眠状態の特 徴を明らかにすることを目的に研究を行った。測定方法は、長時間測定できるタイムラプス ビテオを用いて、子どもの夜間入眠してから朝覚醒するまでを連続してビデオ録画した。録 画やデータの分析に先立って、トレーニングを受け、得られるデータの信頼性を確保した。 その結果、子どもの睡眠・覚醒の特徴は、「眠りの安定性」と「眠りの深さ」によって説明さ れることが明らかになった。(詳細は当日説明したい。)

これまでの研究は、今ある状況のなかで対象理解を主とした記述研究であり、これから続 けていく研究の始まりの部分である。今までの研究結果では、対象の状況を提示するにとど まっている。現在のところ、子どもの睡眠・覚醒の行動観察研究は、あまり手がつけられな かった領域であり、記述研究に位置すると考えている。今後、発達に応じた睡眠状態の変化 を追って記述研究を積み重わていく予定であり、その後、具体的にケアの評価へ発展できる ような研究へ桑げていくことができればと考えている。

臨床における研究は混沌とした中で生まれるものであり、ひとつひとつのなぞを解き明か して、それらを雪だるま式に積み上げていくことが大切であると考える。また、一人で行う よりも他領域と協働することで、より研究の幅が広げられると感じている。 


\title{
ワークショップ 3 ：助産師教育に期待するもの
}

\section{助産師教育に期待するもの}

\author{
座長: 琉球大学保健学科 宮城万里子 \\ 京都府立医科大学医療技術短期大学部 宮中 文子
}

今回この課題がテーマとしてあがった背景には、助産師教育が昭和 23 年に専門職教育と 位置づけられた歴史的変遷と、平成 9 年以降急激に増えた 4 年制大学における保看統合カリ キュラムによる看護学教育がある。

助産師教育は、今日まで看護専門学校に続く養成課程、看護短期大学専攻科など看護課程 修了後の 1 年課程と 4 年制大学で選択科目として位置づけられる教育課程の 3 課程が混在し た状況で行われている。そしてこの状況は当分続くだろうと思われる。4 年制大学の場合、 各大学の助産師課程履修学生数が固定されていないことから、助産師免許資格取得のために 入学しても希望者全員が履修できるわけではない。従って、卒業後新たに養成課程や短大専 攻科に進学し、助産師免許資格取得をめざす学生が年々増えている。また、看護学教育の大 学化が一層進むなか、看護学教育と助産学基礎教育が前後して教育される状況が生じ、助産 学教育開始時の基礎学力と看護学教育両者の境界に不明瞭性を生じている。と同時に看護学 教育においては、卒業後時点における基本技術の到達度の低下が危惧されている現状がある。

助産師教育の現場では、教育の時期をどこに位置づけた方がよいのか、助産師教育協議会 を中心に検討しつつある。そのような中にあって、現状の限られた時間・期間の枠内で教育 のコアとなる部分、社会的にも求められるようになった部分を含めたカリキュラムで教育実 践している施設も多い。

助産学教育のコアとなる部分については、「女性の性と生殖に関わるケアの専門家」として 教育する視点から、周産期を中心に捉えている学校がほとんどである。加えて 21 世紀は、

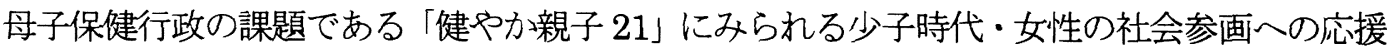
となる子育て支援（育児相談、家族計画、不妊相談）を含め、思春期，更年期女性（男性） のリプロダクティブヘルス・ライツ等女性や子供の問題に対応できる教育カリキュラムが、 社会に貢献できる助産師として自立できるための基礎教育として求められてきている。

このワークショップでは、「助産師教育に期待するもの」を課題にあげ、4人の方にそれぞ れの立場からから話題提供をいただき、これからの助産師教育がどのような展望をもって進 むのが望ましいか、会場の皆様と有益な意見交換ができればと考えている。

演者には、助産師教育に取り組んでおられる浜松医科大学の島田先生。実習現場で助産学 生を教育・指導されている琉球大学付属病院の高島先生と中頭病院の宮城章子先生。地域に 根ざした産科医療をめざし、助産師の力を最大限に活用できる産科医院を開業されている医 師の立場から神谷先生をお願いしています。 


\section{ワークショップ 3：助産師教育に期待するもの}

\section{臨床指導者の立場から}

琉球大学医学部附属病院 高島 美奈子

私が大学病院で 1 人の助産師として助産業務を開始した際、何よりも強く感じたのは「責 任」ということであった。

妊婦検診の際には、医師の診察前に体重や血圧值・尿蛋白結果·浮腫の確認など、助産師が医 師より先に確認できる場がある。検查值などの異常は医師によって発見されフォローされた としても、マイナートラブルや妊婦の抱く不安などの発見に関しては、忙しい外来診療の中で は気づくことが出来ないことにもなりかねない。そうしたサインを見落とす事により、妊産婦 は苦痛を抱いて次回の外来を受けることとなり、状況によっては症状の増悪へと導いてしま う。発見遅れであり、それが保健指導のもれにつながる。病棟においても同じ事が言える。早 期発見・報告は、毎日の業務の中における自分の観察力や解釈・分析・判断・実施がかかってお り、自分の能力や判断力の質が関与してくる。分婏開始徴候の出現から出産に関しても、助産 師の判断が求められる場は、リラックスさせる声掛けやタッチング、マッサージ、照明や香りな ど環境の配慮、N S Tの判断、内診実施や分婏室入室時期の判断など責任重大の場面が多々あ る。「あなたがいてくれて良かった」「この病院で産んで良かった」と妊産婦から声が聞ける 為にも、妊産婦の立場になって考えることが出来、真剣に丁寧に、そして責任を持って知識・技 術面・心のケアが出来る助産師で埋め尽くしたいと思う。この他、産裖期においても助産師の 役割はたくさんある。

母性実習や助産実習の臨床指導者として関わらせてもらっている中、私自身も勉強となる 面はたくさんあり、考えさせられたこと、反省点は数多くある。経験を重ねていく中で理想の 助産師を想っては現状の自分に落ち込むこともある。学生達は、この先卒業後、1人の社会人、 助産師として活動するが、果たしてどれ程の人が切迫感や責任感を抱いているのだろうか。臨 床の場は、学生時代とははるかに異なり、厳しい。卒業すれば学生という殼はもう存在しな い。私は実習において、「自分の行動に責任を持つこと」を強調して伝えるようにしている。 自分の学生時代から今日まで、何に悩み、何に戸惑い、どういったことに感動したのか、振り 返りながら皆さんの意見も参考にし、助産師教育の展望を考えていきたい。

1. 学生だった頃に抱いた理想の助産師について

2. 出産場面に立ち会うことについて

3. 周産期管理における助産師の各々の立場

4. 助産師の持つ顔 


\section{5. 保健指導の難しさ}

6. コミュニケーション技術とタッチング

7. 周産期管理においての継続学習

8. 後輩育成の難しさ

9. 家族看護の重要性

10. 客観的に評価する事の大切さ

11. 研修医、医学生との関わり

上記項目を元にワークショップに望みたいと考えている。さらに、他者の意見を伺うこと で、より自分の助産師観を深めることができたらと期待している。 


\section{ワークショップ 3 : 助産師教育に期待するもの}

\section{女性達の力を引き出せる助産師の育成を！}

特定医療法人敬愛会中頭病院宮城 章子

中頭病院は、326床を有する総合病院である。その中の 21 床が産婦人科病棟で、産婦 人科外来と病棟をプールで管理している。産婦人科外来では、育児支援外来、助産師外来 (保 健指導を中心に実施)、を行っており、地域活動として、2 力所の市の委託事業を受けて「新 生児訪問」の実施と、市からの委託で中学生対象に思春期教室を行っている。

平成 13 年度の年間分婏数は 865 件、内訳として経腟分婏 $88.8 \%$ 、帝王切開 $11.2 \%$ 、 正常分婏がほとんどで、助産師が主に分婏介助に関わっている。

\section{助産実習・卒業生の受け入れ}

当院は、実習指定病院で、助産コースに関しては平成 12 年より沖縄県立沖縄看護学校助 産学科の実習を 2 年間受け入れ、平成 14 年度からは沖縄県立看護大学の実習を受け入れて いる。卒後助産師の採用は毎年 1 ～3 人であるが、看護や助産の基礎技術の習得が不十分な ままの就職となっているため、大学や助産学科で習得した看護理論以前に看護基礎技 術の習得を優先せざるを得ない状況である。

特に実習では、与薬に関しては見学のみで実施はしない、受け持ち患者は 1 人で看護展開 が行なわれる。しかし現場に入ると正常分婏の介助のみではなく、それに付随し点滴や抗生 剂の注射等が必要な事もあり、更に受け持ち患者は 10 人以上となることもあり複数の対象 への看護過程の展開が難しい。実際に実習では経験したことがない技術を現場で要求される ため、新入職員もとまどう事が多い。

教育の場と現場とのギャップに新人助産師はとまどい、また現場の私たちにも看護過程の 展開ができるような状況を十分に整えてあげられないジレンマがある。いかに教育の場と現 場を近づけられるかが課題と考える。

\section{助産教育を大学院で}

助産教育が始まる以前は地域に「とりあげ婆さん」がいて出産の介助が行われ、「育児」に ついは家族の中で行われていた。分婏介助が主な業務であった「とりあげ婆さん」の、時 代から、現在は女性のライフサイクル全てに関わる程助産師業務が桩大されている。そうた 社会の変化と共に助産師に求められることも多い、性の性と生殖に関わるケア」に中心が 
おかれているとは言うものの、変化する社会のニーズに対応できる人材を助産教育で十分に 育成できているとは言い難い。

更に助産教育が始まってから現在に至るまで、実習で「正常分婏 10 例の介助」は変わっ ていない。看護教育の中で、基礎を学んできているはずであるが、学生の生活体験が少なく なる中、現場では看護技術を含め助産技術が未熟なままの就職になる。こうした中で先進国 の中でも少ない「 10 例」の分婏介助で満足していて良いのだろうか。

助産実習において正常娃産婦の分婏介助が中心となっているうえ、裖婦の入院が $5 \sim 6$ 日と短い期間で新生児への関わり、乳房管理、育児指導を行なわなければならない状況で ある。分婏介助も助産師にとって大切なことであるが、分婏後から育児のスタートとなる母 親にとって、分婏介助技術の他に母乳管理技術、新生児管理、退院後の育児指導など周産期 だけに限っても助産師が関わる業務は多い。このような助産業務を 4 年生大学のカリキュラ ムの中で、短期間の実習の中で行なうことには無理があると考える。助産教育を大学院教育 へ移行し、 1 年間はエビデンスに基づく助産技術と理論習得、 2 年目に集中実習を 1 年間実 施する事で理論と実践のつながりを深めていくことができると考える。

\section{女性の力を引き出せる助産師の育成を}

妊娠、分婏は病気ではなく生理的変化で、科学では十分に解明できない神秘性を含んでい る。そうした中、女性の持っている力を引き出し、正常な分婏へと導いていけるのは助産師 の技である。

出産体験はその人のトラウマとも成り得るし成功体験とも成り得る。又それが育児や自分 の生き方、考え方に影響を及ぼしてしまう事もある。分婏が成功体験となったときには、自 分の自信につながり前向きな生き方ができるのではないだろうか。女性の力と能力を引き出 す為には、肯定的な関わり、共感する能力、対象理解等が助産師に求められるが、それと同 時に助産師自身の自己理解と自己肯定感、エンパワメント能力を持つことも大切であると考 える。

最近は「指示待ち」で言われたことしかやらない、等「自立」に欠けていると言われてい るが、助産師にとって、自分で考え行動し、その結果に責任を持つ能力は不可欠だと考える。 助産教育の中で、学生の「感性」と「自立」を育てることができるようなカリキュラムの構 築が必要だと考える。

分婏という大切な時期を女性と向き合える助産師はすばらしい。そのすばらしさと魅力を 学生に伝える助産教育であってほしいと考える。 


\section{助産師教育の実際と展望}

浜松医科大学医学部看護学科 島田三恵子

\section{I 助産師教育の目指すもの・目標}

助産師教育を考える時、女性や子どもあるいは社会のニーズに対する助産の質や助産 師のあり方を抜きに考えることができない。女性や家族にとって妊娠出産育児という現 象は人生の出来事、親になる事、新しい家族を養育するという心理社会的な出来事であ り、生物学的な生殖にとどまらない。妊娠出産は安全、安楽、満足を得るだけでなく自 然の産む力を引き出すことにより自分で産んだという達成感や体験が女性の人生やその 後の育児の様々な状況に対処していく自信を育てる要因の 1 つとなるであろう。

このような出産を最も傍でサポートする助産師の教育では、対象のニーズを把握し信 頼関係を培いながら、独立して正常な妊娠・分婏・産裖に関連した健康現象を診断する 能力が不可欠であり、正常と正常からの逸脱を識別あるいは予測する判断能力を修得す ること、この判断に基づいて、女性の生理的な過程を正常に経過させるケア、危険を回 避する行動、医療を要請するまでの緊急避難的処置など、免許が付与されるプロフェッ ショナルとしての最低基準として安全な実践能力を修得すること、地域母子保健活動を 推進し、開業に必要な基本的な知識能力を修得することが必要とされる。

\section{II 助産師教育の視点}

1. 女性・家族のニーズの洞察と関係性

女性や家族を中心に考え、彼女らのニーズや気持ちを洞察する感性を磨く必要がある。 対象に関心を向けたケアの中で培われる信頼関係の関係性自体が助産ケアの一部である。 2. 女性に備わっている生殖に関する生理的な能力

人体のホメオスターシスと自然治㾑力と同様、殆どの女性の体は自然に妊娠する能力 と同時に生理的に産む能力が備わっている。しかし、妊娠分婏産裖期は心身共に大きく 変化し健康から逸脱しやすい状態にあるため、医療のバックアップは不可欠である。

3. 正常に経過させるサポート

生理的な経過を正常に経過するように援助するのが助産の役割の 1 つである。妊娠を 正常に経過させ周産期の疾患を予防するには妊娠中の正しい生活習慣が、女性の自然な 産む力を引き出して分婏を正常に経過させるには、分婏時に食事、睡眠、排泄、適度な 運動、不安や疼痛（産痛）の軽減など基本的ニーズが満たされた「当たり前の日常生活」 のサポートと、不必要な医療介入や処置しないことが害は重要である。

4. 母親役割への適応と子育て支援

「母親になること」すなわち児のために行動できる母親の自信を育てることは助産師 


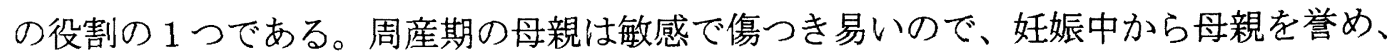
励まし、安心させ、母親役割への適応を支援することが大切である。出産後の母親は周 囲の人々に心理的・物理的に守られる環境を必須条件として、母子が没頭し合える中で 児により引き出される「自然な育てる力」が湧いてくる。

5. 女性と家族のヘルスプロモーション

妊娠出産育児という時期は、健康な妊娠経過を維持するために日常生活を自分で管理 し、生まれた児を健康に育てるために基本的な生活習慣に則った育児を行い躾るという、 女性と家族のへルスプロモーションの好機となる。

6. リスクマネージメントと医療事故

責任を持って助産の医療行為を行う助産業務の特殊性として、助産師独自の業務範囲 と法的責任、医療の訴訟問題とインフォームドコンセント、リスクマネージメントとそ の予防および起きた時の対処や結果責任などに関する教育が必要となる。

\section{III 助産師基礎教育の教育方法・方策}

1）教育の時期

助産講義・実習は 4 年次に配当され、それ以前に母性看護学・小児看護学実習は終了。

2) 履修要件・対象

3 年前期までの必修科目の単位の取得、将来助産師として活動する意志が履修要件。 大学教育カリキュラムの間隙では、実習時期および履修定員の制限がある。

3）教育内容

学部教育の中では助産講義・実習は読み替え科目が多く、指定規則より遙かに少ない。 周産期を中心とした教育内容で、社会が必要な子育て支援、家族計画、不妊相談、思春 期・更年期女性の健康問題に対応できる助産教育に及びにくい。

4) 教育方法

学部での助産師教育方針は、助産師のアイデンティティの芽を持たせ、自主的に勉強 する方法を助産講義の中で徹底的に修得させる事としている。

\section{IV 助産師教育の展望}

助産教育の前提条件として、助産独自のケア、明確な助産哲学の構築が必要である。 継続的なケアを通じた 2 者間の関係性が満足な出産経験をもたらすことから、妊娠期か ら育児期の家庭訪問までを継続して 1 人の学生が受け持つプライマリ実習は人間関係技 法も学ぶ有効な助産教育であり、旧指定規則に定めた 2 例程度体験できれば望ましい。 しかし、このような妊娠から育児期のプライマリ実習、母子とその家族に対する周産期 を中心とした助産ケア、社会での必要性が高まる思春期から更年期に亘る女性の性と生 殖に関するケア等、女性や社会のニーズに応え安全で満足な助産ケアを提供するために 必要な本来の基礎教育期間は、最低 1 年間以上必要ではないかと考えられる。また、自 律した専門職として助産師が生涯学習する基本的な能力を修得するために、臨床事例を 教材にした問題解決技法により学習するチュートリアル教育の検討も期待される。 


\title{
ワークショップ 3 ：助産師教育に期待するもの
}

\section{医師の立場からみた助産師業務と助産師教育}

\author{
かみや母と子のクリニック 院長 神谷 仁
}

私の産科クリニックの目標の一つは、助産師の力を最大限に発揮できるクリニックにした いということでした。助産師が中心となり、妊婦に対し責任をもって考え、ケア (実践)し、 産科医、小児科医、看護師がそれぞれの立場をわきまえて助産師をサポートする体制を作り たいと考えたのです。

これまでの自分が行ってきた妊婦健診を振りかえると、超音波で胎児に異常がないか、頝 管長が短縮して切迫早産になっていないかなど異常を探すことが多く、健診というよりは検 診を行ってきたのではないかと思います。医師の行う妊婦健診は、異常の検索に偏りがちで、 医学的に大きな異常がなければ良とし、あまり経胵分婏にこだわらない傾向があります。

しかし、妊娠する多くの女性は合併症をもっていません。基礎疾患がないにもかかわらず、 何らかの原因で緊急帝王切開分婏になることは少なくありません。このような妊婦は、実は 不健康な状態で妊娠経過をすごしてきて、結果的に帝王切開という異常分婏になってしまっ たのではないかと思うようになり、助産師が中心の体制づくりを考えるようになったのです。

私の考える助産師の仕事とは、妊婦の能力を最大限に引き出せるように働きかけ、妊娠、 分婏を乗り越えられるように指導をすることなのですが、この重大な役割を担っているはず の助産師自身が、そのことを忘れてしまっているのではないでしょうか。正常な娃婦が正常 なままで妊娠、分婏をのりきらせるケア、異常分婏に陥らせないためのケアが助産師の本来 の仕事だと考えます。私は当クリニックの助産師にもそのことを期待し、彼女たちが実践で きるような環境作りと指導を心がけています。

また、妊婦の疾患には詳しいが、妊婦の健康管理をどのようにしていいかわからない助産 師が多いのではないかと思います。おそらく、このようなことを書くと「健康管理なんてオ テノモノ」と思う助産師も少なくないでしょうが、では実際に妊婦の能力を最大限引きだす ために、どのように妊婦に衝きかけしているか考えてみて欲しいと思います。個々の顔が違 うようにそれぞれの分婏経過も違うことを“百も承知” なはずなのに、せいぜい母親学級等 で多くの妊婦を相手にして、型どおりのことを繰り返しているのはなぜでしょう。妊婦の疾 患に詳しくなることも大切なことですが、どうしたら妊婦の健康管理ができ、妊婦が異常に 
陥らずにすむかというケアを勉強すべきであり、その結果、一人でも多くの娃婦が正常の経 過のままで分婏を乗り越えられるよう努力する必要があります。

安全なお産のために、分婏の画一的な管理方法（ある意味でベルトコンベアー化された方 法）により、多くの病院、診療所で安全なお産ができるようなりました。その結果、助産師 は、お産の個別性に沿ったケアを考えることをやめ、安易なルーティンワークに流されてし まったのではないでしょうか。そのような傾向が、おのずと助産師としての力を発揮する場 面を少なくし、現在のような笨地に陥っていると考えられます。このような状態であれば、 医師の中に助産師の必要性を感じない方がいても何ら不思議ではありませんし、多くのこと を期待しなくなっているのも事実です。指示を受けて実行するのは助産師でなくても事が足 りてしまうからです。

また、助産師の仕事を多くの妊婦に理解してもらい、支持を得ることができるならば、助 産師が仕事をきちっとしている病院、診療所なりに妊婦が集まるのではないでしょうか。実 際には、病院の規模、アメニティー、医師あるいは病院のネイムバリューなどが妊婦の病院 選びの選択基準になっています。

現在のシステムでは助産師が十分な力を発揮できる状態ではないことを知ったうえで、あ えて言わせていただければ、助産師が助産師としての正しい評価を受け、正しい地位を獲得 するには、第一に助産師自身の意識改革と各個人の能力の底上げが不可欠です。残念ながら、 多くの助産師の方には妊婦の期待に答えるだけの能力がそなわっているとはいえず、実際に その能力を育てるシステムも構築されているとは思いません。卒前、卒後を含めた助産師教 育が医療の流れ、社会のニーズに対応できていないことが一つの大きな原因と考えられます。

再度、助産師業務の中で助産師が果たすべき責任とは何なのかを助産師教育の中で再確認 する必要を感じます。卒後教育においても基本的なカリキュラムを作って、はっきりした目 標設定をするべきではないでしょうか。そうでなければ、いつまでたっても、分婏経過しか みられない助産師で終わってしまう危険性があります。

正常はより正常に、多少異常があっても、正常な娃娠、分婏にしてしまうような “すばら しい助産師”を一人でも育てるにはどうしたらいいかみんなで話し合いましょう。

これからの助産師に期待を寄せる医師の一人として、今回のワークショップに参加させて いただくことを光栄に思います。日頃、私のクリニックの助産師と話していることが助産師 の皆さんに受け入れられるのか、ためすいい機会と思っておりますので、多くの助産師の方 と意見を交換できることを楽しみにしております。 